\title{
Transformational Decision Making: A Corporate Success Story In Purchasing
}

Diane D. Galbraith, Slippery Rock University, USA Fred L. Webb, Slippery Rock University, USA

\begin{abstract}
The purpose of this case study is to provide a pedagogical teaching tool for undergraduate business students to fully comprehend the importance of the business management functions of planning, organizing, leading and controlling businesses. This case is inspired by events in the history of Rockwell International Corporation. As a major conglomerate struggles to transform itself over a period of eight decades, Rockwell provided a challenging problem for students to solve.
\end{abstract}

Keywords: centralization; decentralization; empowerment; organizing; strategy; conglomerate

\section{INTRODUCTION}

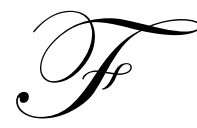

or decades Rockwell International Corporation was a leader in the aerospace industry and commercial businesses. Rockwell's background encompasses 82 years of many mergers, name changes, and changes in business focus. Since 2001 the operations split resulting in two independent companies sharing the same identity, Rockwell Automation and Rockwell Collins. Thus, Rockwell International Corporation ceased to exist.

This case study chronicles the vigorous undertaking of merging two purchasing management styles: (1) a distinguished defense contractor (2) a leader in commercial businesses. There is often conflict between new commercially oriented attitudes and mature military minded attitudes. At times traditional roles, as well as traditional attitudes require yielding to utilizing people, values and systems to continuously change and improve performance based upon where the greatest value is to be realized.

\section{HISTORY}

Rockwell International Corporation has a long history of being one of the United States' true business success stories. In 1888 Willard Frederick Rockwell was born in Boston, MA and in 1978 he died and is buried in Homewood Cemetery, Pittsburgh, PA. Willard Rockwell was trained in engineering, a graduate of Massachusetts Institute of Technology (MIT), and served as a Colonel during World War I. His humble entrepreneurial hard work would begin an 82 year long account of what someday would be defined as a major American manufacturing conglomerate (Soylent, 2011).

In 1915, Willard Rockwell managed the Torbensen Gear and Axle Company, Cleveland, OH. Colonel Rockwell had developed a new bearing system for truck axles and in 1919 purchased Hayes Machine Company, Oshkosh, WI. The firm was renamed Wisconsin Axle. However, in 1921 the recession hit and the company had an oversupply of axles due to a major contract being cancelled. Colonel Rockwell vowed to diversify and never again be at the mercy of one industry, or one customer. In 1928 Wisconsin Axle Company merged with the TimkenDetroit Axle Company.

The Wisconsin Axle Company merged with the Standard Steel Spring Company in 1953, forming the Rockwell Spring and Axle Company. This company was renamed Rockwell-Standard Corporation five years later, after mergers with numerous automotive suppliers in the U.S. and Canada (Rockwell International CorporationCompany History, 2010). 
Colonel Rockwell's entrepreneurial efforts had evolved into being a leading maker of automotive components. During these years he also acquired the Pittsburgh Equitable Meter and Manufacturing Company and renamed it Rockwell Manufacturing Company.

In 1967 Pittsburgh, PA based Rockwell-Standard Corporation purchased and merged with a major U.S. defense contractor Los Angeles, CA based North American Aviation. The company had earned a distinguished record for product success. In support of President Kennedy's challenge to land a man on the moon by 1970, North American Aviation built the Apollo space capsule. During testing the Apollo space capsule was destroyed resulting from a flash fire killing three astronauts. North American Aviation suffered financial losses that threatened it with bankruptcy or a prime candidate for a takeover. When Rockwell-Standard purchased North American Aviation the company was four times the size of Rockwell-Standard Corporation. The new company was named North American Rockwell Corporation (Rockwell International Corporation-Company History, 2010).

Rockwell Manufacturing Company and North American Rockwell Corporation merged in 1973, to become Rockwell International Corporation with their corporate headquarters in Pittsburgh. Robert Anderson became Chairman and Chief Executive officer in 1979 and was widely known for his strong leadership in the aerospace and defense and commercial businesses (News Release, 2010). In the same year Donald R. Beall became President and Chief Operating Officer and a valued compliment to Anderson's management style. Don Beall has been described by associates as a tough, but fair visionary leader with an acute memory for details and a quick mind (Miller, 1996).

Under Anderson's and Beall's leadership Rockwell progressed in the aerospace business by becoming the major contractor for the Space Shuttle, the B1B bomber and various aerospace components, defense electronics, Peacekeeper missiles and the Navstar Global Positioning System satellites.

In the commercial businesses Rockwell acquired the Miehle-Goss-Dexter printing press business, the Allen-Bradley Company, Sprecher and Schuh (a Swiss automation company), Reliance Electric, and expanded their commercial electronics and telecommunications. Combined with the existing Automotive and Truck business, the Valve and Meter business Rockwell International Corporation grew to approximately $\$ 12$ billion in sales with assets over $\$ 8$ billion. During the 1980s Rockwell's workforce exceeded 100,000 employees, organized into seven major divisions and the corporation was \#27 on the Fortune 500 list (Miller, 1996).

\section{THE PROBLEM}

Rockwell International Corporation was an extremely diversified Corporation creating complex management challenges. Now they are faced with the process of transitioning from being two separate companies to merging the defense focused organization and the commercial business focused organization. Along with the balance between government and commercial businesses, this new change has a profound impact on the daily purchasing operations.

What are the objectives needed to bring about a successful transition while the conflicts inherent in such a significant merger are beyond measure? The corporate staff purchasing function is now located in Pittsburgh and consist mainly of line managers from the former North American Aviation, which was located in Los Angeles. The culture of North American Aviation was driven by the military defense contracting systems of tight controls based upon the government's Defense Acquisition Regulations System (DARS).

The corporate staff purchasing function in Rockwell became one of the major bottle-necks for the operating divisions. Divisional purchasing directors from both the government and commercial businesses were constantly expressing concerns about the time delays for corporate purchasing staff to approve divisional purchasing decisions. The corporate purchasing staff was over-whelmed by the daily quantity of divisional request for approvals.

The corporate purchasing policy and procedure book was in excess of 600 pages. The procedure book was based upon the North American Aviation's government DARS requirements and a corporate Pittsburgh's staff delegation of authority that provided little leeway for decisions by the operating divisions. The operating divisions were developing "work-a-round" procedures to expedite the purchasing functions. These management challenges 
were recognized and were slowly being dealt with to bring about the balance between the corporate purchasing staff and the diverse divisional purchasing management responsibilities (McCarty, 1983).

To address some of these management issues, Rockwell conducted a management search to hire an individual with the skills, ability and experience to develop the purchasing function at the corporate office. The corporate Vice President of Purchasing was J. B. Sayer, a respected former North American Aviation executive well versed in the government DARS policies and procedures. However, Mr. Sayer had announced his intentions to retire and at a time when Rockwell was emerging as a major diversified conglomerate in both government and commercial businesses.

The executive search resulted in the hiring of Bruce L. Hoover, an executive with the General Motors Corporation, Detroit, MI. Mr. Hoover was an experienced operations line and staff manager both in the domestic and international arenas. He was an Alfred P. Sloan Scholar and graduate of the Sloan School of Management at Massachusetts Institute of Technology (MIT). Rockwell appointed him corporate Vice President of Materials Management having staff responsibilities for procurement, logistics, and material control and planning.

A strategic management study was conducted of the corporate staff and the divisions. All of the corporate purchasing policies and procedures were reviewed. A plan was required to address the needs of the operating divisions respecting the needs of government contracting, commercial businesses and the roles of the corporate purchasing staff and operating divisions.

A philosophical evolution towards a more "entrepreneurial leadership" not only for purchasing, but for the total concept of materials management was needed at the corporate purchasing staff and the division operating levels. Most U.S. corporations were placing a focus upon materials management, not just the purchasing function. This was necessary because Rockwell's businesses were mature for the most part with good personnel.

The first step was to take a fresh look at the role of the corporate purchasing staff organization. What were they doing and why? The divisional purchasing organizations were required to send all purchase orders in excess of $\$ 1,000$ to corporate office for approval regardless of the type of purchase. Rockwell's total purchases amounted to over $\$ 3$ billion per year and forecasted to reach over $\$ 5$ billion per year.

Table 1. Distribution Of Purchase Orders

\begin{tabular}{|c|c|c|c|c|}
\hline $\begin{array}{c}\text { Dollar Value of } \\
\text { Purchase Order }\end{array}$ & $\begin{array}{c}\text { Number of Purchase } \\
\text { Orders }\end{array}$ & $\begin{array}{c}\text { Total Dollars } \\
\text { Allocated }\end{array}$ & $\begin{array}{c}\text { Percent of Purchase } \\
\text { Orders Issued }\end{array}$ & $\begin{array}{c}\text { Percent of Total } \\
\text { Dollars Allocated }\end{array}$ \\
\hline$<\$ 1,000$ & 705,000 & $\$ 154,000,000$ & $76 \%$ & $4 \%$ \\
\hline$>\$ 1,000$ & 226,000 & $\$ 3,672,000,000$ & $24 \%$ & $96 \%$ \\
\hline Totals & 931,000 & $\$ 3,826,000,000$ & $100 \%$ & $100 \%$ \\
\hline
\end{tabular}

These figures are an approximate account of the total annual purchase orders for Rockwell. The divisions' work-a-round the corporate purchasing office approval process is reflected in the percent of purchase orders. Over $76 \%$ of purchase orders were approved at the division level.

The amount of paperwork generated and number of signatures required just to fulfill this procedure was beyond the scope of the corporate purchasing staff. Purchases generally averaged about $44 \%$ of sales. To avoid this requirement and to meet the lead time needs divisional purchasing staff was issuing purchase orders for less than $\$ 1,000$. These actions created increased paperwork and lead time delays at a tremendous cost (McCarty, 1983).

The principal objective of the purchasing function is to procure required goods and services in a manner that will: (1) contribute substantially to divisional and corporate earnings (2) perpetuate its reputation for honest, fair and ethical dealings throughout industry. Purchasing obligations extend beyond the regular responsibilities to secure adequate supplies of the proper quality, quantity, at the right place and time. This is accomplished by purchasing value: quality, quantity, reliability, and service commensurate with cost (McCarty, 1983). 
A Purchase Order Flow Chart

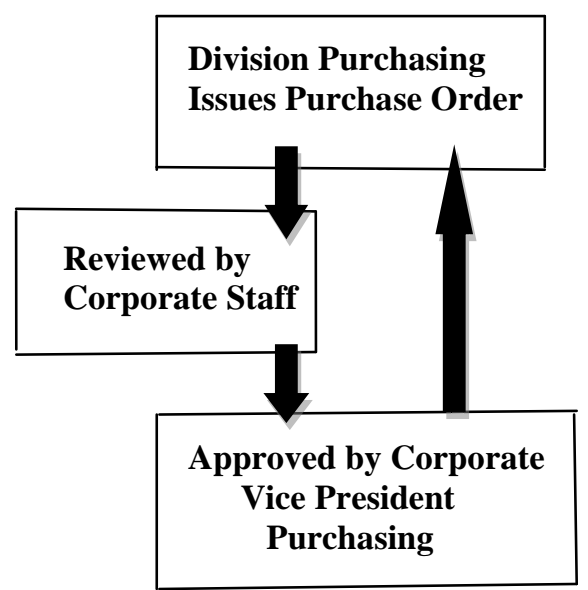

Figure 1. This is an example of how one purchase order request in excessive of $\$ 1,000$ required a minimum of three approval signature levels. Even with the divisional work-a-round efforts, corporate purchasing staff was handling approvals of 226,000 purchase orders a year, averaging approximately 940 a day. The total number of signature transactions for the 226,000 purchase orders multiplied by 3 amounted to 678,000 signature transactions per year.

\section{VALUE ADDED PURCHASING}

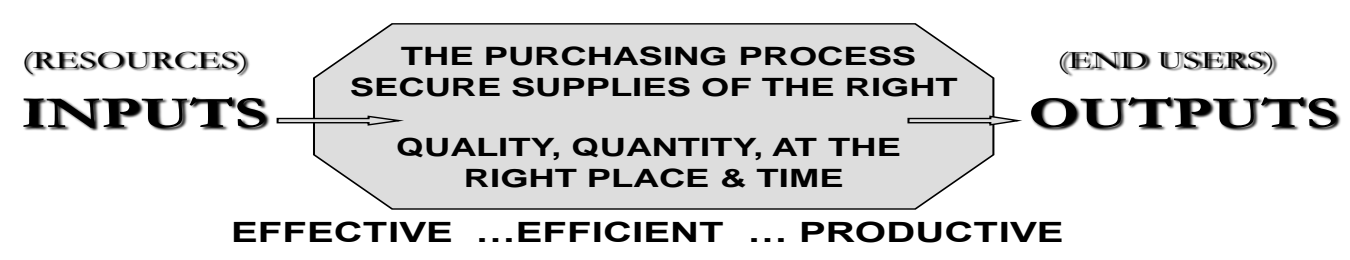

Figure 2. The principal objective of the purchasing function is to secure supplies to add value for the end users. Strive to make structures and processes as simple as possible for employees, suppliers and customers. Effective by attaining goals, efficient by assisting with financial growth and be productive with inputs and outputs.

\section{RESULTS}

The new corporate materials management staff for Rockwell was an improved approach given Rockwell's current growth status. The corporate materials management staff focused upon a more loosely structured approach of advising and suggesting with fewer tightly established procedures. The role of corporate materials management staff became one of making recommendations, a more advisory approach with the line or divisional personnel and not being directly involved in making decisions concerning the day to day operations of the divisions (Greenberg, 2011). This provided the divisions with opportunities to be creative and more entrepreneurial in conducting their daily materials management activities. Following are a few of the benefits, occurring in the first year, as a result of this realignment: 
- $\quad$ A corporate wide team of materials management personnel was established to coordinate common material purchases obtaining volume discounts for all divisions resulting cost reduction of $\$ 10$ million.

- $\quad$ A corporate wide logistics study resulted in eliminating the Rockwell private interstate trucking fleet. By sub-contracting with local trucking firms under the new deregulated interstate trucking laws, the corporation cost reduction amounted to $\$ 22$ million. An additional cost reduction of $\$ 6.3$ million resulted from competitive bidding of divisional transportation activities.

- $\quad$ Commercial divisions established international procurements resulting in $\$ 353.4$ million in worldwide expenditures for cost reductions of $\$ 25$ million.

- $\quad$ An additional $\$ 13$ million in cost reductions from miscellaneous procurement activities.

- $\quad$ Strategic guidelines were established for commercial divisional manufacture or purchase decisions. This policy was designed to insure that capital expenditures were being utilized efficiently.

- A Director of Government Contracts position was established in the Rockwell Los Angeles office to insure proper controls, quality and lead time management for government contracts. This was beneficial in providing effective and efficient performance in completing the B1B bomber program under budget and ahead of schedule for the U.S. Air Force.

- The realignment of materials management staff and line responsibilities created an opportunity for improving the personnel planning, recruiting and selection of materials management personnel to assist Rockwell in building a better, faster, and more competitive organization. Materials management personnel were recognized for corporate wide promotional opportunities. This exposure resulted in promotions to general management positions for the high performing personnel.

In addition to the benefits listed previously, a materials management advisory council was formed with a goal of identifying key issues affecting the corporation's materials management. How do we improve performance in managing our external manufacturing and our supply base? We want to make our personnel professional managers of external manufacturing. We strive to have managers that offer value-added inputs to our manufacturing divisions, improving the value-added to the end use product and service for our customers.

Likewise, the materials management team must work in synergy with the other business disciplines by being fully engaged in the strategic and operational planning processes. The council works to improve lead times or thru-put management, thus, acquiring the right materials at the right times within the cost budget targets. The B1B program managers, as well as the high technology electronics divisions, implemented the basic concepts of improving lead times resulting in creating shorter and shorter build and buy cycles for over-all productivity improvements (McCarty, 1983). 
Rockwell International Corporate Purchasing Staff

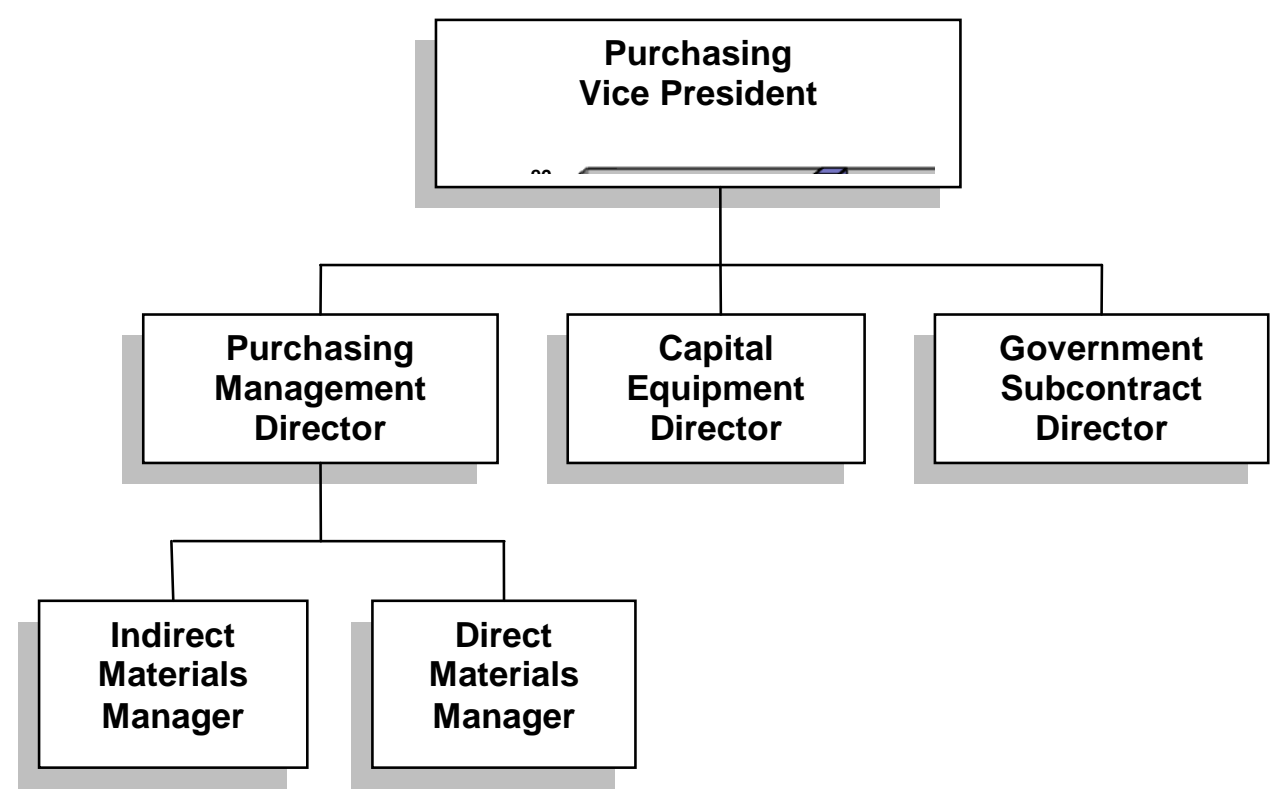

Figure 3. This is an approximate representation organizational chart utilized by Rockwell's corporate purchasing staff before the re-structuring to a Materials Management Corporate Staff. All operating divisions were required to submit purchase orders and contracts over $\$ 1,000$ to the corporate staff for approvals prior to issuance. The staff consisted of line managers from the North American Aviation acquisition.

Rockwell International Corporate Materials Management Staff

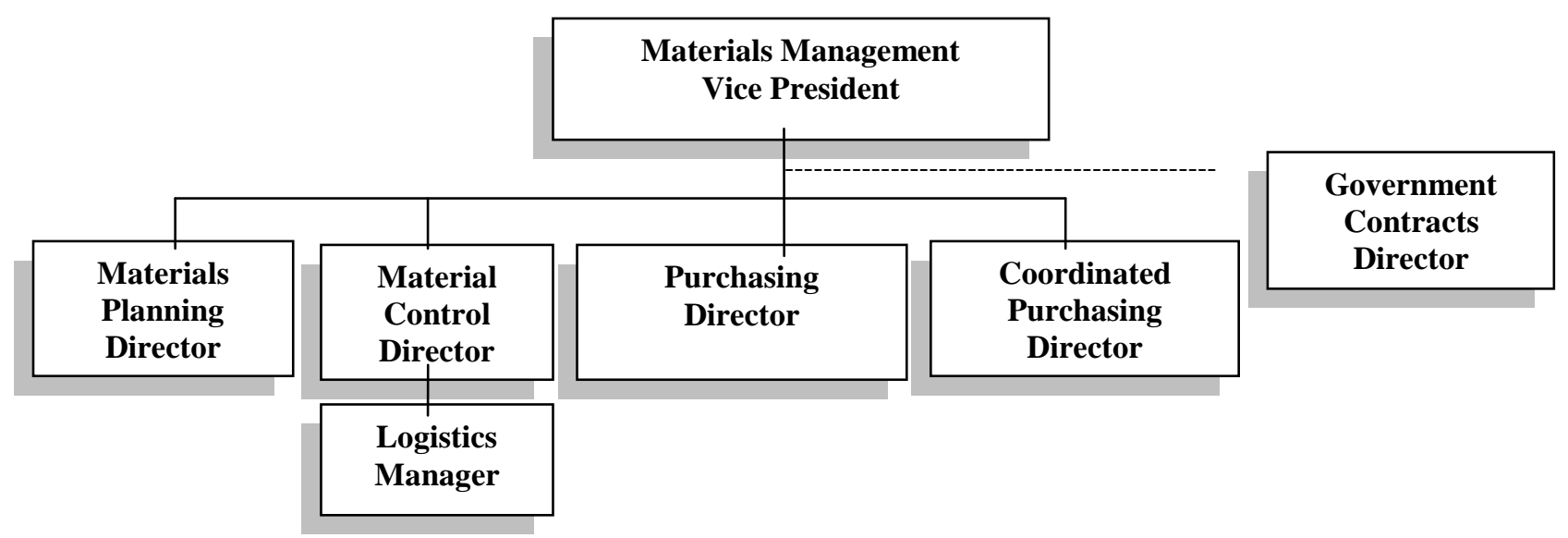

Figure 4. This organization chart represents the basic new re-structured staff from purchasing to materials management. The staff provided required materials management policies and served primarily in an advisory role to the operating divisions. The materials management personnel were recruited as specialist in their fields.

\section{CONCLUSION}

In 1988, Robert Anderson retired and Don Beall became Rockwell's Chairman and Chief Executive Officer. The completion of the Space Shuttle program and the final production of the B1B bomber led to a major decline in Rockwell's revenues. Don Beall was faced with developing a new business strategy, one that would diversify the company and take it in a different direction, away from government contracts (Donlon, 1996). 
The end of the cold war and deteriorating economic conditions added emphasis to accelerating the new strategy. Rockwell International Corporation, as a highly diversified conglomerate, did not fall prey to the issues of size and life cycle during its 82 year history. Research indicates that organizations tend to become more bureaucratic as they grow in size and consequently have more difficulty adapting to the changing environments (Schermerhorn, 2002).

Rockwell's management was historically known for planning strategically being keenly aware of its opportunities, threats, strengths, and areas for improvements. Don Beall emphasized: "We are not a holding company or a conglomerate in the traditional sense. We feel Rockwell works better as an organic whole, rather than a collection of independent companies". Beall goes on to point out that understanding Rockwell's "core competencies" is critical and that the common thread now uniting the company is "technology," a key to the divestitures, or shedding of business segments (Miller, 1996).

Obviously, the end of the cold war and a forecasted decline in defense and aerospace programs provided the threats that needed to be offset by new opportunities to sustain growth, even if the corporation had to become smaller. Consequently, Rockwell's management keeping with basic precepts that the corporation's businesses must be market leaders and have growth potential, embarked upon a "sorting out" resulting in 27 divestitures and 46 acquisitions (Donlon, 1996).

What is Rockwell today? Rockwell International Corporation, a truly American management success story...does not exist...being replaced by Rockwell Automation and Rockwell Collins.

This case is an excellent model of a real world example of applying business strategy principles that transform distinctly different cultures and businesses into a value-added successful decentralized purchasing function.

\section{DISCUSSION QUESTIONS}

Students are to research this company in advance and prepare to discuss in class the basic principles of management that correlates with this Rockwell International Corporation case study. They are to locate three management references on the web and include them in their typed responses to the following questions:

1. Why does the phrase: "Structure follows Strategy" become so important in organizational design?

2. Explain the concepts of centralization and decentralization of business structures. What are the benefits and risks associated with these organizational concepts? Develop examples from the case and explain each.

3. The "Loose-Tight" principle of management is an appropriate focus for doing business. Explain how this principle applies or does not apply to the Rockwell case.

4. List and explain some of the management issues related to a diversified conglomerate corporation like Rockwell International Corporation.

The goal is to engage the students, after their assignment preparations, in quality discussions concerning business organizational trends that are changing the workplace. As a learning experience, students are encouraged to work in teams and brain storm ideas for preparing their individual reports.

\section{AUTHOR INFORMATION}

Diane D. Galbraith is a Business Professor in the School of Business at Slippery Rock University, Slippery Rock, and PA. She is a graduate of Indiana University of Pennsylvania (IUP) earning a BS in Business Administration, with a major in Marketing and Management. She earned her MS in Management and HRM from La Roche College. She earned her doctorate in Administration and Leadership from IUP. Her background includes almost 20 years in the business world. She has 11 years of teaching traditional and non-traditional students at both the undergraduate and graduate level. Her main research interests are adult learning, emotional intelligence, ethics, academic integrity and leadership. 
Fred L. Webb is Associate Professor of Business in the School of Business at Slippery Rock University, Slippery Rock, PA. He earned his BS degree in Education from Ball State University. He holds a MS degree in Management from Massachusetts Institute of Technology (MIT). He is a graduate of Duquesne University earning his Doctor of Education. Dr. Webb has extensive domestic and international management experiences in line, divisional and corporate staff positions. He has served as a senior level management consultant for both profit and non-profit businesses. His main research interests are business ethics and strategic planning.

\section{REFERENCES}

1. Bolman, L.G. and Deal, T. E. (2003). Reframing organizations, ( $3^{\text {rd }}$ Ed.), San Francisco, CA: Jossey-Bass.

2. De Kluyver, Cornelis A., Pearce II, John A. (2009). Strategy A View from the Top, Upper Saddle River, NJ: Pearson/Prentice Hall.

3. Donlon, J. (1996). Rockwell comes in from the cold war, an interview with Rockwell International CEO,Don Beall, Retrieved December 3, 2010 at: http://find articles.com.

4. Gamble, A. E. and Thompson Jr., A. A. (2008). Essentials of strategic management, Boston MA: McGrawHill.

5. Greenberg, J. (2011). Behavior in organizations $\left(10^{\text {th }}\right.$. Ed.) Upper Saddle River, NJ: Prentice Hall/Pearson.

6. McCarty, J. R. (1983). Restructuring the purchasing function, Purchasing Magazine, Vol.95 (8), Cahners Publication. (pp. 44-50).

7. Miller, W. H. (1996). Don Beall: Conglomerater, Industry Week Magazine, Vol.245/No.2. Penton Publication. (pp. 12-16).

8. News Release: Robert Anderson, former Rockwell International Chairman, dies at 85. Retrieved November 25, 2010 at: http:// www.rockwellcollins.com..

9. Rockwell International Corporation-Company History (2010). Retrieved December 3, 2010 at: http://www.fundinguniverse.com/companyhistories.

10. Soylent Communications, NNDB: Willard Rockwell aka Willard Frederick Rockwell (2011). Retrieved January 10, 2011 at: http://www.nndb.com/people/232/000178695/.

11. Schermerhorn, J. R., Hunt, J.G., Osborn, R. N. (2008). Organizational behavior, (10 ${ }^{\text {th }}$ Ed.). Hoboken, NJ: John Wiley \& Sons, Inc.

12. Schermerhorn, J. R. (2006). Management, $\left(8^{\text {th }}\right.$ Ed.), Hoboken, NJ: John Wiley \& Sons, Inc.

13. Sloan, A. P. (1965). My years with General Motors. New York: Macfadden Books. 